\title{
THE QUALITY AND IMPORTANCE OF GROUNDWATER IN THE ESCARPMENT ZONE OF THE BUG RIVER VALLEY
}

\section{JAKOŚĆ I ZNACZENIE WÓD GRUNTOWYCH W STREFIE KRAWĘDZIOWEJ DOLINY BUGU}

\author{
Klaudia Wołyńczuk $^{1(\mathrm{D}, \mathrm{E}, \mathrm{F})}$, Anna Rogóż-Matyszczak ${ }^{1(\mathrm{~B}, \mathrm{C}, \mathrm{D})}$, \\ Marta Zarębska $^{1(B, C, D)}$, tukasz Zbucki ${ }^{1(A, B, D, F, G)}$
}

${ }^{1}$ Pope John Paul II State School of Higher Education in Biała Podlaska, Poland

Authors' contribution Wkład autorów:

A. Study design/planning zaplanowanie badań B. Data collection/entry zebranie danych C. Data analysis/statistics dane - analiza i statystyki D. Data interpretation interpretacja danych E. Preparation of manuscript przygotowanie artykułu F. Literature analysis/search wyszukiwanie i analiza literatury G. Funds collection zebranie funduszy
Tables: 5

Figures: 0

References: 30

Submitted: 2020 Jun 8

Accepted: 2020 Jul 24

\section{Summary}

Background. The use of groundwater from private wells in households is increasing significantly. However, this water is usually untreated, making it a carrier of diseases. Chemical composition plays a key role in assessing groundwater quality. Due to rapid urbanization and industrialization of the environment, pollutants (especially toxic elements) are constantly being released into the aquatic environment and pose a threat to human and animal health. There is a large variety of microorganisms in aquifers. The use of groundwater from aquifers as sources of drinking water without water treatment or disinfection is a public health problem. Material and methods. The material for the study consisted of water samples taken from used and unused domestic wells in villages located in Lubelskie Province, Biała Podlaska County, Janów Podlaski municipality, Poland. ICP-OES was used to determine the composition of elements. The total number of mesophilic and psychrophilic bacteria was determined for 5 wells using the pour-plate method according to the Polish Standard PN-EN ISO 6222:2004.

Results. The water from the wells is unfit for consumption due to high microbiological contamination. A study would have to be carried out on the content of specific pathogenic microorganisms. In most of the samples analyzed, the heavy metal content of the water is below admissible limits.

Conclusions. Water resources of the highest quality should be increasingly protected and retained as drinking water reserves. This is extremely important in view of the progressing climate change and the slow process of groundwater renewal.

Keywords: hydrology, groundwater, water microbiology, wells, water geochemistry

\section{Streszczenie}

Wprowadzenie. Zużycie wody gruntowej ze studni prywatnych w gospodarstwach domowych znacznie wzrasta. Jednakże woda ta jest zwykle nieoczyszczona, co czyni ją nośnikiem chorób. W ocenie jakości wód podziemnych kluczową rolę odgrywa skład chemiczny. Z powodu szybkiej urbanizacji i uprzemysłowienia środowiska, zanieczyszczenia (zwłaszcza toksyczne pierwiastki) są stale uwalniane do środowiska wodnego i stanowią zagrożenie dla zdrowia ludzi i zwierząt. W warstwach wodonośnych występuje duża różnorodność mikroorganizmów. Problemem zdrowia publicznego jest wykorzystywanie warstw wodonośnych wód podziemnych jako źródeł wody pitnej bez procesu oczyszczania wody lub dezynfekcji.

Materiał i metody. Materiał do badań stanowiły próby wody pobrane z użytkowanych i nieużytkowanych studni przydomowych we wsiach położonych w województwie lubelskim, powiecie bialskim, w gminie Janów Podlaski. W celu oznaczenia zawartości pierwiastków wykorzystano metodę ICP-OES. Dla 5 studni określono ogólną liczbę bakterii mezofilnych i psychrofilnych przy wykorzystaniu metody płytek lanych zgodnie z Polską Normą PN-EN ISO 6222:2004.

Wyniki. Woda pochodząca ze studni nie nadaje się do spożycia z uwagi na wysokie zanieczyszczanie mikrobiologiczne. Konieczne byłoby przeprowadzenie badania na zawartość konkretnych mikroorganizmów chorobotwórczych. W większości analizowanych prób zawartość metali ciężkich w wodzie znajduje się poniżej dopuszczalnej granicy.

Wnioski. Zasoby wodne o najwyższej jakości powinny być poddane coraz większej ochronie i pozostawione jako rezerwa wód pitnych. Jest to niezwykle istotne $\mathrm{z}$ uwagi na postępującą zmianę klimatu oraz powolny proces odnawiania wód podziemnych.

Słowa kluczowe: hydrologia, wody podziemne, mikrobiologia wód, studnie, geochemia wód 


\section{Introduction}

Surface and groundwater resources are essential in order to meet domestic, agricultural and industrial needs [1]. Taking into account hydrological aspects and geographical location, water resources in Poland are limited. In previous years, the average amount of total surface water resources was $61.6 \mathrm{~km}^{3}$ including inflows from across the border. In turn, total individual resources per capita amount to $1839.3 \mathrm{~m}^{3} /$ year (1946-2011), and individual own resources per capita $1590 \mathrm{~m}^{3} /$ year [2,3], which places Poland second lowest in Europe in terms of water resources. The main task of water management is to optimize the use of water resources and ensure safety with regard to flooding or drought [4]. According to the information published by the Chief Inspectorate of Environmental Protection, the condition of groundwater is better than that of surface water. The EFA report [5] shows that about $74 \%$ of the surface of groundwater showed good chemical status compared to only about $40 \%$ of surface waters. In addition, significant progress has been made in recent years in identifying and removing sources of contamination of groundwater and surface water [6].

The consumption of groundwater from private wells in households is increasing significantly, due to the lower cost of maintaining the wells than the water supplied by the waterworks. However, this water is usually untreated, which makes it a carrier of diseases [7-9]. In uncontaminated water systems, the main ions are released through rock weathering and water quality is related to factors such as the composition of precipitation, geological structure, mineralogy of aquifers, geological processes within the aquifer and waterrock interactions $[8,10]$. The interaction of all these factors results in different water composition. Increased knowledge of the geochemical evolution of groundwater in dry and semi-arid regions may lead to a better understanding of hydrochemical systems in such areas, resulting in sustainable development of water resources and effective groundwater management [10]. Among the factors influencing the deterioration of water quality are many different natural and anthropogenic processes: agriculture, industry and energy production, mining, uncontrolled waste disposal, population growth, urbanization and climate change [11]. Moreover, the degradation and contamination of groundwater is also related to the depth and type of wells, the presence of rubbish dumps and cemeteries, improper maintenance or abandonment of wells and improper use of cesspits [9]. The above factors also significantly affect surface and groundwater resources [10-12]. Due to rapid urbanization and industrialization of the environment, pollutants (especially toxic elements) are systematically released into the aquatic environment and pose a threat to human health $[12,13]$.

The susceptibility of groundwater to pollution depends on three factors:

1. presence of artificial or natural sources of contamination,

2. chemical and physical surface processes that affect the concentration of contaminants in groundwater,

3. ease of flow of water and contaminants into and through the aquifer [14].

Chemical composition plays a key role in the assessment of groundwater quality [8]. Hydrochemical testing makes it possible to assess water in order to determine its suitability for consumption, for agricultural and industrial purposes. The main groundwater ions are $\mathrm{Ca}^{2+}, \mathrm{Mg}^{2+}, \mathrm{Cl}^{-}, \mathrm{HCO}^{3-} \mathrm{Na}^{+}, \mathrm{K}^{+}$and $\mathrm{SO}_{4}^{2-}$. Their composition plays an important role in the classification and assessment of water quality. Activities related to agriculture and urbanization are the main factors that contribute to changes in chemical composition and eutrophication of bodies of water. The understanding of the impact of urbanization on water ecosystems has gained in importance due to the increase in population in urban centers and the increasing use of urban water systems for consumption $[10,15]$.

The lack of monitoring of groundwater quality and regulations governing the way wells are drilled results in the population consuming water that has not been adequately treated. Moreover, domestic wells are not subject to sanitary supervision. Water consumption without proper quality control constitutes a threat to public health [7]. Hazardous groundwater contaminants include heavy metals as well as pesticides. The main source of which is fruit farming, agriculture and forest management, due to the significant quantities of plant protection agents used in these areas. The consumption of water contaminated with pesticides can lead to allergies, liver, kidney and nervous system damage, and can also exhibit mutagenic and carcinogenic properties [16]. Once groundwater is contaminated, its quality cannot be restored by stemming the source of contamination. Therefore, it is necessary to regularly observe the standards regarding groundwater and formulate ways to protect it, as water quality is crucial for human and animal health [12].

The main public health problem is the use of aquifers as sources of drinking water without water treatment or disinfection [17]. Water pollution by microorganisms resistant to many drugs is also a problem as it is a source of proliferation of antimicrobial resistance [9]. The penetration of surface water carrying animal waste or sewage into groundwater abstraction wells can lead to gastrointestinal diseases, since fecal material can contain various pathogenic micro-organisms. The most common agents causing these diseases are 
noroviruses, Campylobacter, Cryptosporidium, Giardia and pathogenic bacilli E. coli. To a lesser extent: rotavirus, Shigella, hepatitis A, Salmonella and Toxoplasma [17]. To minimize the risk of water-borne diseases, sensitive water resources should be identified and appropriate preventive measures such as disinfection or the use of appropriate filters applied. It is therefore important to monitor and assess the microbiological quality of water from boreholes and manually dug wells, as they provide a basis for effective management strategies to improve the quality of water from those sources $[9,17,18]$

The aim of the study was to assess the quality and suitability of groundwater for consumption and agricultural purposes.

\section{Material and methods}

The material for the study consisted of 3 samples of water from each well taken from used and unused domestic wells located in villages in Lubelskie Province, Biała Podlaska County, Janów Podlaski municipality, Poland. The samples were taken during the spring. The characteristics of the wells are presented in Table 1.

Table 1. Well characteristics

\begin{tabular}{|c|c|c|c|c|c|c|}
\hline $\begin{array}{c}\text { Type } \\
\text { of well }\end{array}$ & Sample & Village & $\begin{array}{c}\text { Date of } \\
\text { collection }\end{array}$ & $\begin{array}{c}\text { Water } \\
\text { temperature } \\
\left({ }^{\circ} \mathbf{C}\right)\end{array}$ & $\begin{array}{c}\text { Air } \\
\text { temperature } \\
\left({ }^{\circ} \mathbf{C}\right)\end{array}$ & $\begin{array}{c}\text { Water table } \\
\text { level (m) }\end{array}$ \\
\hline \multirow{2}{*}{ Used } & $\mathrm{P}$ & Peredyło & $11^{\text {th }}$ March 2019 & 2.8 & 1.0 & 1.95 \\
\cline { 2 - 7 } & $\mathrm{BG}$ & Bubel Granna & $16^{\text {th }}$ April 2019 & 5.0 & -1.3 & 3.5 \\
\hline \multirow{3}{*}{ Unused } & $\mathrm{NP}$ & Nowy Pawłów & $11^{\text {th }}$ March 2019 & 7.1 & 1.0 & 7.6 \\
\cline { 2 - 7 } & $\mathrm{JP}$ & Janów Podlaski & $26^{\text {th }}$ May 2019 & 9.6 & 18 & 1.75 \\
\cline { 2 - 7 } & $\mathrm{BL}$ & Bubel Łukowiska & $16^{\text {th }}$ April 2019 & 8.0 & -1.3 & 13.9 \\
\hline
\end{tabular}

Elemental analysis using ICP-OES

Concentrated nitric acid and hydrochloric acid were added to the analyzed samples at a 3:1 ratio. The samples were then filtered through filter paper. In order to determine the calcium content, the samples were diluted 20 times and the measurement was repeated. ICP OES analysis was carried out using the SpectroBlue spectrometer at the Regional Centre for Environmental, Agricultural and Innovative Technologies EKO-AGRO-TECH of Pope John Paul II State School of Higher Education in Biała Podlaska. Calibration solutions were prepared using the standards: Bernd Kraft Der Standard Spectro Genesis ICAL and VHG SM68-1-500 Element Multi Standard 1 in $5 \%$ HNO3. Each sample was measured three times. The results are given in $\mathrm{mg} / \mathrm{l}$. Among all measured elements (Al, Ba, Cd, Co, Cr, Cu, Fe, La, Li, Mn, Nd, Ni, Pb, Pr, Se, Sr, Th, U, V, Zn, As, S) the content of the major elements (Ca, $\mathrm{K}, \mathrm{Mg}, \mathrm{Na}, \mathrm{S}$ ), trace elements (Ba, Fe, La, Li, P, Sr, V) and heavy metals (Al, As, Cd, Cr, Cu, Mn, Ni, Pb, Se, U, Zn). The content of other elements was below the detection limit.

\section{Microbiological analysis}

Water samples from the wells were taken in accordance with Polish Standard PN-EN ISO 19458:2007 [19]. For 5 wells the total number of mesophilic bacteria (growing at $36 \pm 2^{\circ} \mathrm{C}$ for $44 \pm 4 \mathrm{~h}$ ) and psychrophilic bacteria (growing at $22 \pm 2^{\circ} \mathrm{C}$ for $68 \pm 4 \mathrm{~h}$ ) was determined using the pour-plate method in accordance with Polish Standard PN-EN ISO 6222:2004 [20]. In pilot studies for 2 wells, the number of $\beta$-D-glucuronidase positive Escherichia coli and Enterobacteriaceae (other than $\beta$-D-glucuronidase positive E. coli) was quantified by inoculation using the chromogenic medium REBECCA ${ }^{\mathrm{TM}}$ AEB620027 with the addition of REBECCA ${ }^{\mathrm{TM}}$ SUPPLEMENT EB AEB184135 by BIOMÉRIEUX according to the manufacturer's instructions. The colonies that grew on the substrates were counted and given in $\mathrm{cfu} / \mathrm{ml}$.

\section{Results and discussion}

The mostcommon and widespread health riskassociated with drinking water ismicrobiological contamination. Aquifers are inhabited by a huge variety of microorganisms. They are most often found at shallow depths. Some microorganisms can play a key role in the subsurface biogeochemical cycle and degradation of contaminants. Since groundwater usually contains low concentrations of organic carbon, their microbiological life depends mainly on oxidation and reduction of inorganic compounds for energy. Therefore, geochemical conditions, 
and in particular the availability of electron donors and acceptors, are a major factor in the development of microorganisms in groundwater and the geological substrate [7].

The research carried out (Table 2) shows that wells from which water is systematically extracted are characterized by lower microbiological contamination than unused wells. According to the Regulation of the Minister of Health on the quality of water intended for human consumption [21] it is recommended that the total number of microorganisms in tap water should not exceed $200 \mathrm{cfu} / \mathrm{ml}$. In the following case, well water is unfit for consumption due to high microbiological contamination. It would be necessary to test for specific pathogenic microorganisms, e.g. Cryptosporidium.

Table 2. Results of microbiological analyses of well water, total bacteria count at $22 \pm 2{ }^{\circ} \mathrm{C}$ and $36 \pm 2^{\circ} \mathrm{C}$

\begin{tabular}{|c|c|c|c|}
\hline Type of well & Sample & $\begin{array}{l}\text { The total number of bacteria at } \\
22 \pm 2^{\circ} \mathrm{C}[\mathrm{cfu} / \mathrm{ml}]^{*}\end{array}$ & $\begin{array}{l}\text { The total number of bacteria at } \\
36 \pm 2^{\circ} \mathrm{C}[\mathrm{cfu} / \mathrm{ml}]^{*}\end{array}$ \\
\hline \multirow{2}{*}{ Used well } & $\mathrm{P}$ & $6.4 \times 10^{2}$ & $4.7 \times 10$ \\
\hline & BG & $1.7 \times 10^{3}$ & $3.4 \times 10$ \\
\hline \multirow{3}{*}{ Unused well } & NP & $5.9 \times 10^{3}$ & $1.1 \times 10^{3}$ \\
\hline & $\mathrm{JP}$ & $1.0 \times 10^{4}$ & $5.5 \times 10^{2}$ \\
\hline & $\mathrm{B} \succeq$ & $8.5 \times 10^{2}$ & $1.3 \times 10^{3}$ \\
\hline
\end{tabular}

Notes: *fu - colony forming units.

The determination of the total number of $E$. coli bacteria is an indicator used to assess water quality [22]. These bacteria belong to the family Enterobacteriaceae. They are characterized by the ability to produce the $\beta$-D-glucuronidase enzyme, and from which they can be identified. E. coli bacteria compared to other coliform bacteria and Enterobacteriaceae are considered an indicator of fecal water contamination. On the basis of pilot studies carried out for the presence of $\beta$-D-glucuronidase positive $E$. coli, these bacteria were not found in the tested samples. The obtained results show that water intakes are protected against the inflow of contaminants of this kind. In the cases of analysis of Enterobacteriaceae other than $\beta$-D-glucuronidase positive E. coli, these were detected only in the BŁ sample from an unused well (Table 3). However, they have not been identified. According to Cabral [23], Enterobacteriaceae include, among others, species such as Klebsiella, Enterobacter, Citrobacter, which live in animal and human intestines, but also occur naturally in the environment and are easily isolated from soil, contaminated water and plants.

Table 3. Results of microbiological analyses of well water, total number of $\beta$-D-glucuronidase positive $E$. coli and Enterobacteriaceae other than $\beta$-D-glucuronidase positive $E$. coli

\begin{tabular}{|c|c|c|}
\hline Sample name & $\boldsymbol{\beta}$-D-glucuronidase positive E. coli $[\mathbf{c f u} / \mathbf{m l}]^{*}$ & $\begin{array}{c}\text { Enterobacteriaceae other than } \\
\boldsymbol{\beta} \text {-D-glucuronidase positive } \text { E. coli }[\mathbf{c f u} / \mathbf{m l}]^{*}\end{array}$ \\
\hline BG & No presence found & No presence found \\
\hline B & No presence found & $1.4 \times 10$ \\
\hline
\end{tabular}

Notes: *cfu - colony forming units.

In many aquifers, differences in water quality may be related to seasonal changes in water demand. In summer, water from wells is drawn much more often than in winter due to its use for household supply and land irrigation. The intensity of well use can cause considerable variability in hydrological conditions, especially with regard to horizontal and vertical hydraulic gradients that drive the transport of contaminants through the groundwater system. Changes in the direction or size of hydraulic gradients caused by seasonal pumping may be particularly pronounced in areas where surface water reserves are insufficient to meet summer water demand [24]. Differences in hydrogeological circulation result in distinct geochemical composition of groundwater, e.g. changes in the content of atmospheric oxygen and chemical compounds originating from agriculture. The annual replenishment of groundwater provides a relatively constant inflow of oxygen from the surface to weathered zone of aquifers, as well as chemical elements resulting from intensive agriculture, such as nitrates and leaching of fertilizers. Conversely, groundwater in the fractured zone is relatively protected and relatively isolated. However, even regional hydrogeological loops are to some degree mixed with groundwater from the weathered zone and do not represent fully isolated ecosystems [25].

The chemical characteristics of groundwater are also influenced by minerals and gases reacting with water in its relatively slow passage through rocks and sediments of the earth's crust. Basically, groundwater has a high mineral content as it flows through pores and fissures in rocks. Therefore, the deeper the water, the more mineralized it is [26]. 
Health concerns related to the chemical composition of drinking water differ from those related to microbiological contamination and are mainly related to the ability of the chemicals to cause adverse health effects after a prolonged period of exposure. Groundwater with high salinity levels may increase the risk of hypertension, while a deficiency of elements such as calcium and magnesium in drinking water may increase the risk of mortality from ischemic heart disease in humans. In contrast, drinking water containing, for example, high concentrations of sulphates can have a laxative effect, and high nitrate levels can cause a disease called methemoglobinemia (which consists of replacing hemoglobin in the body with methemoglobin). Heavy metals present in drinking water (such as: $\mathrm{As}, \mathrm{Cd}, \mathrm{Cr}, \mathrm{Cu}, \mathrm{Mn}, \mathrm{Pb}, \mathrm{Zn}$ ) may cause cognitive disorders, cardiovascular diseases and cancer. Arsenic is classified as the most dangerous element present in drinking water due to its high toxicity and the fact that, depending on geological conditions, groundwater may have a high level of this element [8]. Table 4 shows the major elements and trace elements. The major elements (Ca, K, Mg, Na, S) occur in high concentrations in the analyzed water samples. High calcium contents indicate that the water is hard. For water from used wells, a significantly lower magnesium content and higher sodium content were observed compared to samples from unused wells. The NP water sample from an unused well has a much higher content of elements such as: $\mathrm{K}, \mathrm{Fe}$, P compared to the other wells. This may be due to local conditions such as the use of fertilizers on agricultural land, resulting in the leaching of nutrients from the soil and infiltration into water and soil [27]. Potassium is an element that is easily transferred from soil to groundwater. Its high content in the NP sample may be dependent on how the meadows are used and may also be related to the storage of manure directly on the ground near the well site [28].

Table 4. Average content of major elements and trace elements in well water [mg/l]

\begin{tabular}{|c|c|c|c|c|c|c|}
\hline \multicolumn{2}{|c|}{ Elements } & \multicolumn{3}{c|}{ Unused wells } & \multicolumn{2}{c|}{ Used wells } \\
\cline { 3 - 8 } & & NP & JP & BL & \multicolumn{2}{c|}{ BG } \\
\hline \multirow{4}{*}{ Major elements } & $\mathrm{Ca}$ & 109.604 & 206.658 & 246.541 & 115.953 & 116.858 \\
\cline { 2 - 8 } & $\mathrm{K}$ & 60.047 & 3.375 & 2.865 & 36.690 & 13.988 \\
\cline { 2 - 8 } & $\mathrm{Mg}$ & 12.996 & 15.313 & 20.207 & 9.980 & 6.163 \\
\cline { 2 - 8 } & $\mathrm{Na}$ & 15.301 & 13.977 & 12.013 & 21.137 & 29.169 \\
\cline { 2 - 8 } & $\mathrm{S}$ & 6.264 & 4.177 & 19.856 & 6.285 & 5.084 \\
\hline \multirow{4}{*}{ Trace elements } & $\mathrm{Ba}$ & 0.016 & 0.0357 & 0.0517 & 0.022 & 0.03 \\
\cline { 2 - 8 } & $\mathrm{Fe}$ & 0.670 & 0.062 & 0.113 & 0.043 & 0.123 \\
\cline { 2 - 8 } & $\mathrm{La}$ & 0.004 & $<0.001$ & $<0.001$ & 0.003 & $<0.001$ \\
\cline { 2 - 8 } & $\mathrm{Li}$ & 0.005 & 0.017 & 0.026 & 0.003 & 0.014 \\
\cline { 2 - 8 } & $\mathrm{P}$ & 1.111 & 0.657 & 0.041 & 0.0803 & 0.551 \\
\cline { 2 - 8 } & $\mathrm{Sr}$ & 0.186 & 0.125 & 0.133 & 0.176 & 0.085 \\
\cline { 2 - 8 } & $\mathrm{V}$ & 0.047 & 0.048 & 0.061 & 0.035 & 0.016 \\
\hline
\end{tabular}

Both the major and trace elements occur naturally in groundwater, although their varying content may result from natural factors (presence of minerals in the soil) or environmental factors caused by human activity. Average heavy metal content in the analyzed groundwater was compared with WHO standards (Table 5).

Table 5. Summary of the heavy metal content of the wells studied and the World Health Organization (WHO) recommended heavy metal values in drinking water [mg/l] [16]

\begin{tabular}{|c|c|c|c|c|c|c|}
\hline \multirow{2}{*}{ Element } & \multirow{2}{*}{$\begin{array}{c}\text { Recommended } \\
\text { content } \\
{[\mathbf{m g} / \mathbf{l}]:}\end{array}$} & \multicolumn{3}{|c|}{ Unused wells } & \multicolumn{2}{c|}{ Used wells } \\
\cline { 3 - 7 } & 0.2 & NP & JP & BL & P & BG \\
\hline $\mathrm{Al}$ & 0.01 & $<0.018$ & $<0.018$ & $<0.018$ & $<0.018$ & $<0.018$ \\
\hline $\mathrm{As}$ & 0.003 & $<0.001$ & $<0.001$ & $<0.001$ & $<0.001$ & $<0.001$ \\
\hline $\mathrm{Cd}$ & 0.05 & $<0.004$ & $<0.004$ & $<0.004$ & $<0.004$ & $<0.004$ \\
\hline $\mathrm{Cr}$ & 2 & 0.014 & 0.003 & 0.003 & 0.003 & 0.007 \\
\hline $\mathrm{Cu}$ & 0.5 & 0.012 & $<0.001$ & 0.052 & $<0.001$ & 0.004 \\
\hline $\mathrm{Mn}$ & 0.02 & 0.001 & $<0.001$ & $<0.001$ & 0.001 & $<0.001$ \\
\hline $\mathrm{Ni}$ & 0.01 & 0.015 & 0.015 & 0.017 & 0.013 & 0.016 \\
\hline $\mathrm{Pb}$ & 0.01 & $<0.031$ & $<0.031$ & $<0.031$ & $<0.031$ & 0.031 \\
\hline $\mathrm{Se}$ & 1.4 & 0.147 & 0.098 & 0.106 & 0.142 & 0.078 \\
\hline $\mathrm{U}$ & 3 & 0.246 & 0.104 & 0.227 & 0.093 & 0.134 \\
\hline $\mathrm{Zn}$ & & & & &
\end{tabular}


In most of the samples analyzed, the heavy metal content of the water is below the acceptable limit. For arsenic, the detection limit was $<0.018$ and for selenium, the detection limit was $<0.031$. The lead content in each sample slightly exceeded the WHO recommended level. Elevated concentration of lead in natural waters increases mainly due to anthropogenic activities [29].

\section{Conclusions}

Water is an excellent solvent and also a carrier of contaminants. The physical properties of water mean that contaminants can be transported over long distances and that is why it is necessary to ensure the purity and high quality of water [2,3]. The obtained results suggest that groundwater resources should not be used as a source of drinking water without control analyses due to high microbiological contamination. The European Environment Agency claims that water shortages cause losses in farming and affect food production. One reason for this is, among other things, forest felling, which greatly reduces natural retention [30]. According to Gutra-Korycka [2] water resources of the highest quality should be increasingly protected and maintained as a drinking water reserves. This is extremely important due to the progressing climate change and the slow process of groundwater renewal.

\section{Disclosures and acknowledgements}

The research was financed by the Science Development Fund of Pope John Paul II State School of Higher Education in Biała Podlaska, Poland.

\section{References:}

1. Smith R, Knight R, Fendorf S. Overpumping leads to California groundwater arsenic threat. Nature Communications. 2018; 9: 2089. https://doi.org/10.1038/s41467-018-04475-3

2. Gutry-Korycka M, Sadurski A, Kundzewicz ZW, Pociask-Karteczka J, Skrzypczyk L. [Water resources and their use]. Nauka. 2014; 1: 77-98 (in Polish).

3. Gutry-Korycka M. [Flowing water resources in Poland, conditions, use, changes]. Gospodarka Wodna. 2018; 8 (in Polish).

4. Ministry of Marine Economy and Inland Navigation. [Water management in Poland in 2016-2017. Information from the minister in charge of water management]. Warsaw: Ministry of Marine Economy and Inland Navigation; 2018 (in Polish).

5. European Environment Agency. European waters. Assessment of status and pressures 2018. EEA Report, No 7/2018. Luxembourg: Publications Office of the European Union; 2018. https://doi.org/10.2800/303664

6. Environmental Protection Inspection. Groundwater quality monitoring [Internet]. Warsaw: Environmental Protection Inspection [cited 2020 May 20]. Available from: http://mjwp.gios.gov.pl/ badania/ogolne-informacje.html (in Polish).

7. Maran NH, Do Amaral Crispim B, Iahnn SR, Pires De Araújo R, Barufatti Grisolia A, Pires De Oliveira KM. Depth and well type related to groundwater microbiological contamination. International Journal of Environmental Research and Public Health. 2016; 13(10): 1036. https://doi.org/10.3390/ijerph13101036

8. Mora A, Mahlknecht J, Rosales-Lagarde L, Hernández-Antonio A. Assessment of major ions and trace elements in groundwater supplied to the Monterrey metropolitan area, Nuevo León, Mexico. Environmental Monitoring and Assessment. 2017; 189: 394. https://doi.org/10.1007/s10661-017-6096-y

9. De Giglio O, Barbuti G, Trerotoli P, Brigida S, CalabreseA, Di Vittorio G, et al. Microbiologicaland hydrogeological assessment of groundwater in southern Italy. Environmental Monitoring and Assessment. 2016; 188 : 638. https://doi.org/10.1007/s10661-016-5655-y

10. Hosseinifard SJ, Aminiyan MM. Hydrochemical characterization of groundwater quality for drinking and agricultural purposes: a case study in Rafsanjan Plain, Iran. Water Quality, Exposure and Health. 2015; 7: 531-544. https://doi.org/10.1007/s12403-015-0169-3

11. Llopis-González A, Sánchez AL, Requena PM, Suárez-Varela MM. Assessment of the microbiological quality of groundwater in three regions of the Valencian Community (Spain). International Journal of Environmental Research and Public Health. 2014; 11: 5527-5540. https://doi.org/10.3390/ijerph110505527

12. Mohamed AK, Liu D, Song K, Mohamed MAA, Aldaw E, Elubid BA. Hydrochemical analysis and fuzzy logic method for evaluation of groundwater quality in the North Chengdu Plain, China. International Journal of Environmental Research and Public Health. 2019; 16: 302. https://doi.org/10.3390/ijerph16030302 
13. Cao X, Lu Y, Wang CH, Zhang M, Yuan J, Zhang A, et al. Hydrogeochemistry and quality of surface water and groundwater in the drinking water source area of an urbanizing region. Ecotoxicology and Environmental Safety. 2019; 186: 109628. https://doi.org/10.1016/j.ecoenv.2019.109628

14. Eberts SM. If groundwater is contaminated, will water from the well be contaminated?. Ground Water. 2014; 52(1): 3-7. https://doi.org/10.1111/gwat.12260

15. Long J, Luo K. Elements in surface and well water from the central North China Plain: enrichment patterns, origins, and health risk assessment. Environmental Pollution. 2020; 258: 113725. https://doi.org/10.1016/j.envpol.2019.113725

16. Cabalska J, Mikołajczyk A, Palak-Mazur D, Wołkowicz W. [Occurrence of pesticides in the measurement points of groundwater chemical status monitoring]. Przegląd Geologiczny. 2015; 63(10/1): 635-638 (in Polish).

17. Lutterodt G, De Vossenberg JV, Hoiting Y, Kamara AK, Oduro-Kwarteng S, Foppen JWA. Microbial groundwater quality status of hand-dug wells and boreholes in the Dodowa area of Ghana. International Journal of Environmental Research and Public Health. 2018; 15(4): 730. https://doi.org/10.3390/ijerph15040730

18. Pitkänen T, Karinen P, Miettinen IT, Lettojärvi H, Heikkilä A, Maunula R, et al. Microbial contamination of groundwater at small community water supplies in Finland. Ambio. 2011; 40(4): 377-90. https://doi.org/10.1007/s13280-010-0102-8

19. PN-EN ISO 19458:2007 [Water quality - taking samples for microbiological analyses] (in Polish).

20. PN-EN ISO 6222:2004 [Water quality - quantitative labeling of microorganisms able to grow - determination of the total colonies number by the method of culture on nutrient agar] (in Polish).

21. [Regulation of the Minister of Health on the quality of water intended for human consumption of $7^{\text {th }}$ December 2017 (Journal of Laws 2017, item 2294)] (in Polish).

22. Matuszewska R, Krogulska B, Maziarka D. [E. coli bacteria in water intended for human consumption meaning and threats to the health safety. Proceedings in case of the increased values of the concentration]. Warszawa: Główny Inspektorat Sanitarny; 2018 (in Polish).

23. Cabral JPS. Water microbiology. Bacterial pathogens and water. International Journal of Environmental Research and Public Health. 2010; 7(10): 3657-3703. https://doi.org/10.3390/ijerph7103657

24. Bexfield LM, Jurgens BC. Effects of seasonal operation on the quality of water produced by public-supply wells. Ground Water. 2014; 52(1): 10-24. https://doi.org/10.1111/gwat.12174

25. Maamar SB, Aquilina L, Quaiser A, Pauwels H, Michon-Coudouel S, Vergnaud-Ayraud V, et al. Groundwater isolation governs chemistry and microbial community structure along hydrologic flowpaths. Frontiers in Microbiology. 2015; 6: 1457. https://doi.org/10.3389/fmicb.2015.01457

26. Emenike PG, Nnaji CH, Tenebe IT. Assessment of geospatial and hydrochemical interactions of groundwater quality, southwestern Nigeria. Environmental Monitoring and Assessment. 2018; 190: 440. https://doi.org/10.1007/s10661-018-6799-8

27. Ruba E. [Analysis of legal conditions of water management in the area of supplying the population with potable water in Poland]. Ekonomia i Środowisko. 2016; 3(58): 111-125 (in Polish).

28. Burzyńska I. [Potassium in soil, plants and shallow ground waters in relation to different meadow utilisation]. Woda - Środowisko - Obszary Wiejskie. 2012; 12(37): 49-58 (in Polish).

29. Muqtada MAK, Umar R, Lateh H. Study of trace elements in groundwater of Western Uttar Pradesh, India. Scientific Research and Essays. 2010; 5(20): 3175-3182.

30. Suchożebrski J. [Water resources in Poland] [Internet]. Warsaw: Global Compact Network Poland; 2018 [cited 2020 May 20]. Available from: https://ungc.org.pl/info/zasoby-wodne-polski/ (in Polish). 